\title{
Fabrication Optical Filters to Enhance the Contrast for Black and White Photomicrograph Film
}

\author{
Ismail K. Abbas \\ Department of Physics \\ College of Science \\ Mosul University
}

\author{
Soory A. Daher \\ Basic Science Branch \\ College of Agriculture \\ Mosul University
}

Khider A. Salaih

Department of Physics

College of Science

Mosul University

(Received 4 / 8 / 2009 ; Accepted 2/ 11 / 2009)

\begin{abstract}
In this research we fabricated a gelatin optical filter to enhance the contrast in black and white photomicrograph film for biological stained specimen with the basic fuchsin dye.

From the absorption and transmission spectra of different dyes with different concentrations, the results show that the mixture of methyl green and methyl orange with weight ratio(8/1)of concentrations (0.044 and 0.356) $\mathrm{gm} / \mathrm{L}$ are in a good agreement with that of standard filter .
\end{abstract}

\section{تصنبعمرشحك بصربة الزباة التبلين في التصوبر ألمجهري بالفلم الأبيض والسمود}

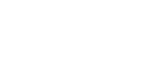

قم في هذا البهث تصنبع مششح جيلاتيني بصري لزياة التباين في التصوير ألمجهري + الفلم الأس ـود والأبيض للنماذج البيولوجية المصبوغة بصبغة فيوجين الأنسلسية. من خلال درلسة لُٔيف الامتصاصية والفانية لأصباغ مختلفة ذات ترلكيز مختلفة، لظٔلهرت النتائج بلن

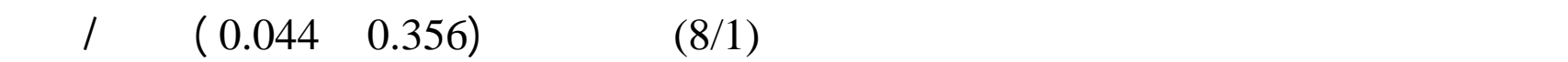
أعطت نتائج مطابقة بصورة جية مع المرشحلت القيلسية. 